Article

\title{
Does Social Inducement Lead to Higher Open Innovation Investment? An Experimental Study
}

\author{
Shuanping Dai ${ }^{1, *(1)}$ and Guanzhong Yang ${ }^{2}$ \\ 1 the Institute for East Asian Studies, and Mercator School of Management, University of Duisburg-Essen, \\ 47057 Duisburg, Germany \\ 2 the IN-EAST School of Advanced Studies, University of Duisburg-Essen, 47057 Duisburg, Germany; \\ guanzhong.yang@uni-due.de \\ * Correspondence: shuanping.dai@uni-due.de; Tel.: +49-203-3791938
}

Received: 17 February 2020; Accepted: 6 March 2020; Published: 9 March 2020

\begin{abstract}
This study, by conducting a laboratory experiment, investigates whether social inducement can be an external instrument to promote open innovation. The study's findings suggest that social inducement, on average, leads subjects to invest more in open innovation projects. In particular, in an asymmetric inducement setting, both induced and non-induced subjects invest more and are more active in open innovation compared to a full inducement setting. Furthermore, economic uncertainty increases the effectiveness of social inducement, suggesting that open innovation is easier to promote in the presence of economic uncertainty. Our findings may suggest practitioners and policymakers applying public channels to communicate open innovation concepts with the public, which in turn helps the adoption of open innovation.
\end{abstract}

Keywords: open innovation; social inducement; economic uncertainty; asymmetric inducement

\section{Introduction}

Open innovation is "a distributed innovation process based on purposively managed knowledge flows across organizational boundaries" [1], and enables a faster and more efficient knowledge transfer, sharing, acquisition, and recombination [2-5]. By opening organizational boundaries, inter-firm cooperation may accelerate flows of knowledge and innovation, and eventually help the individual firms' business success [6,7]. However, potential threats of emerging innovation, in particular, massive digitalization, to sustainability development require our extensive concerns at the social dimension $[8,9]$. Open innovation has received increasing attention in sustainability studies [10-13]. For instance, studies on open sustainable innovation (e.g., [14]) have demonstrated that the open innovation paradigm can achieve both innovation and sustainability goals by lowering entering cost to market and conveying sustainability conceptions along value chains. Research on the adoption of open innovation has investigated the intrinsic economic motivation, which reflects individual's desire to perform for its own sake [15], of firms and individuals to collaborate [16-27]. However, for many companies, open innovation is still not an easily adoptable innovation paradigm, considering its associated risks in knowledge sharing, information protection, and so forth, as compared to the long-lasting dominating closed innovation paradigm $[19,22,28]$. For the crowdsourcing instance, only the firms participating in open innovation can extract value from the crowd and may enjoy positive market feedback, although they are incentive by monetary and social rewards [29-31]. Hence, increasing potential benefits to compensate for risks presents a natural way for open innovation adoption. However, literature also suggests that informative inducement also can change risk perception [32].

This study moves beyond conventional incentive-risk reasoning investigates whether social inducement may act as an external push for individuals and firms to engage in open innovation 
or increase their adoption of open innovation. We investigate this issue through laboratory experiments (for a discussion of the experimental and behavioral approaches in innovation studies, see, for instance, $[33,34])$. In particular, we examine whether informing people of the advantages and disadvantages of open innovation can induce them to participate in open innovation. Please note that we are not going to discuss innovation in the public sector and administration (e.g., [35,36]), although public administration can be a way to implement social inducement to the private sector innovation (e.g., [37-39]), which we focus on.

Social inducement is a one-directional top-down communication and information approach. It can be monetary (such as public procurement, tax rate adjustments, or subsidies to research and development (R\&D) and non-monetary (information inducement, propaganda, and regulations, for example). In the real world, innovation is not only the product of economic maximization incentives but also depends on firms' awareness of innovative solutions [40]. Hirschman [41] explores the functionality of 'inducement mechanisms' for creating institutional circumstances and processes in which decision-making is 'induced' and routinary rather than 'autonomous' and uncertain. Veugelers [42] evidences that the Belgian government has successfully stimulated private environmental technology innovations by introducing investment incentives, tax measures, and tariffs. Similar induced effects have also been proven, for example, in the energy sector [43,44], food sector [45], and so forth. However, the conventional economic and business literature has rarely focused on non-monetary inducement, which may be practicable and is typically implemented via public channels, such as posters, newspapers, television, and radio programs. By accumulating information on interventions, economic actors may be fully informed; however, information may be biased and even manipulated.

The literature has focused on the influence of inducement in various contexts [46-48]. DellaVigna and Kaplan [49] find that Fox News, a pro-Republication television news channel, convinced $3 \%-28 \%$ of its non-Republican audience to vote Republican and significantly increased the Republican voting share in presidential elections by $0.4 \%-0.7 \%$ points between 1996 and 2000. Similarly, Yanagizawa-Drott [50] shows that the main radio station broadcasting propaganda during the Rwandan genocide significantly increased participation in violence. Kearney and Levine [51] argue that the MTV show 16 and Pregnant led to a $4.3 \%$ reduction in teen births in the USA and conclude that public media can be a powerful driver of social outcomes. Experimentalists also have addressed the impact of various types of communication (including face-to-face communication, chatrooms, and cheap talk), which is a type of inducement, on the contribution level in a public good game. The results show that communication can be a valid mechanism to promote cooperation in different ways [52-56]. Our study also contributes to the literature on nudging (e.g., $[57,58]$ ) by featuring the significance of direct information intervention.

We propose that participation to open innovation may be higher when businesses are well informed of the advantages and disadvantages of taking part in open innovation. To test this proposition, we use a video as the means of social inducement in a laboratory experiment. Three social inducement settings are considered. First, a No-Video setting, where subjects do not watch the video; second, a Video setting, where all subjects watch the video; and third, a Half-Video setting, a case of asymmetric inducement, where only half the subjects (randomly selected) in each group watch the video before decision-making. This experimental setting allows us to differentiate induced and non-induced agents in different social inducement scenarios.

This study moves beyond the conventional economic maximization framework and provides a unique perspective to the open innovation literature, and contends that open innovation should become common knowledge among firms through strategic social inducement. This study shows that social inducement can help increase the awareness of firms about open innovation, on average. However, the strategic design and implementation of inducement should be the core elements of this strategy. The study's results suggest that, first, firms cannot be induced to be part of open innovation by the advantages of being open; instead, inducing a specific group that can lead open innovation may generate better results. Second, the Half-Video setting generates a more substantial contribution compared to the full-Video setting in the presence of investment uncertainty. Our findings 
indicate that it might reduce transaction cost, for example, in terms of establishing a collaborative contract, if business practitioners would strategically communicate open innovation concepts and successful practices with their business partners and customers in the regular business contacts and activities. Furthermore, policymakers also can communicate open innovation ideas with the public, via newspaper, for example, to activate the sleeping patents and ongoing projects working together, which may fundamentally reduce the fiscal cost to stimulate innovation activities.

The remainder of this paper is structured as follows. Section 2 develops two theoretical models, upon which the experiments are based. Section 3 describes the experimental design and the variation of treatment parameters and details the experimental procedures. Section 4 presents the experimental results and analyses the impacts of social inducement under various decision-making scenarios, and Section 5 concludes the study.

\section{Theoretical Models}

We assumed that there are $n$ decision-making individuals in the market. Each decision-maker can invest his/her resources $E$ in two projects: traditional innovation $y_{i}$ and open innovation $z_{i}$, where $y_{i}+$ $z_{i}=E$.

\subsection{Model 1: An Open Innovation Investment without Uncertainty}

We began by modeling open innovation based on the public good framework, which is inspired by the ideas of organizations that collaborate in open source projects $[59,60]$. Beyond the standard public good approach, the proposed model suggests that the spillover benefits of open innovation to conventional innovation represent a core motivation for investing in the former. When firms are exposed to external ideas and resources through open innovation projects, they may also obtain knowledge that proves beneficial for their own technology and product development (for an early investigation of this phenomenon, see, [61]).

For example, the Japanese company Denso Wave, inventor of the Quick Response (QR) Code, has several patents on the $\mathrm{QR}$ code but does not enforce its patent rights. The company allows everyone to freely use the QR code within international standards, thus allowing more and more companies to develop technologies based on the QR code. This strategy also helps Denso Wave maintain the competitiveness that derives from the wide adoption of QR codes. Google developed the mobile operating system Android with OS platforms and shared it with other hardware companies. Such an open innovation model allowed Android to become the most popular operating system and attached a large number of customers to Google's products through Android. From the conventional perspective, commercial enterprises that operate in open innovation programs represent an enigma, and the open innovation paradigm should not have become successful (e.g., $[62,63])$. Therefore, a significant challenge for open innovation is to encourage firms and individuals to share their ideas, innovations, and knowledge across the firm's boundaries, thus becoming a key source of innovation [21] and stimulating cooperation in R\&D among firms [4].

We began by addressing a particular situation, where no investment uncertainty. An individual decision-maker decides to assign his/her resources $E$ to different kinds of projects, one of which is open innovation, the so-called public good pool. Every unit $z_{i}$ contributed to the open innovation project by any individual will bring $b_{0}$ unit to every agent. The parameter $b_{0}$ measures the public good's marginal per capita return (MPCR), which indicates the private return rate from the public good pool, i.e., from the total open innovation investment in this case. At the end of the investment, the open innovation's payoff is $\left(z_{i}+z_{-i}\right)\left(1+b_{0}\right)$, where $z_{-i}$ is the amount of open innovation investment from the others.

Aside from the open innovation investment, individual investors can also invest in traditional innovation projects. The rate of return of the traditional innovation investment consists of two parts: one is the benchmark return, denoted by $a_{0}$, and the other is the spillover from the open innovation 
investment, denoted by $a_{1}$. We assume that spillover effects follow a quadratic function. Hence, we obtain:

$$
a_{1}=\frac{-c}{(n E)^{2}}\left(z_{i}+z_{-i}\right)^{2}+\frac{2 c}{n E}\left(z_{i}+z_{-i}\right)
$$

where $c$ is the maximum reachable $a_{1}$. The relation between $a_{1}$ and total open innovation investment $z_{i}$ $+z_{-i}$ is illustrated in Figure 1 .

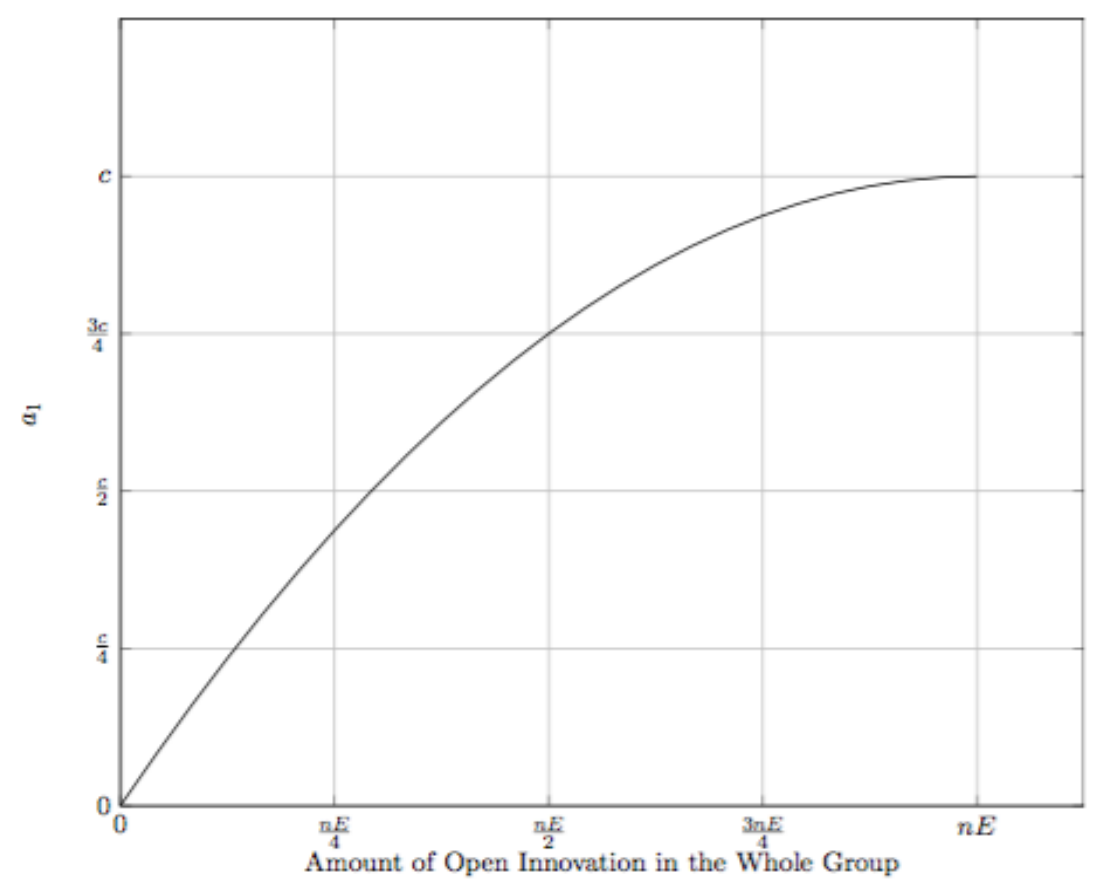

Figure 1. The spillover of open innovation.

Thus, the payoff function that individual firms maximize, subject to the constraint of total initial capital $E$, reads:

$$
\operatorname{Max}_{y i, z i} \Pi_{i}=y i\left(1+a_{0}+a_{1}\right)+\left(z_{i}+z_{-i}\right)\left(1+b_{0}\right),
$$

The optimal open innovation investment level $z_{i}^{*}$ reads as follows:

$$
z_{i}^{*}=\frac{4 n E+2 E-4 z_{-i}-\sqrt{\left(4 n E+2 E-4 z_{-i}\right)^{2}-12\left(z_{-i}^{2}-2 E z_{-i}-2 n E^{2}+\left(b_{0}-a_{0}\right) \frac{n E^{2}}{c}\right.}}{6},
$$

Furthermore, if we assume symmetry, that is, $z_{i}=z$ and $z_{-i}=(n-1) z$, everyone invests the same amount in the open innovation project. Hence, we obtain:

$$
z^{*}=\frac{4 E+2 n E-\sqrt{(4 E+2 n E)^{2}-4(2+n)\left(2 E^{2}+\left(b_{0}-a_{0}\right) \frac{n E^{2}}{c}\right.}}{2(2+n)},
$$

This is the symmetric Nash equilibrium solution. In addition, if we assume that all group resources are collectively distributed, we obtain a socially optimal solution. The total investment return level for all investors is determined by the following profit maximization equation:

$$
\operatorname{Max}_{Y, Z} \Pi=Y\left(1+a_{0}+a_{1}\right)+n Z\left(1+b_{0}\right)
$$


where $\Pi=n \Pi_{i}$ and $Y+Z \leq n E$. Then, we obtain the socially efficient open innovation investment level, as follows:

$$
Z^{\#}=\frac{6 n E-\sqrt{(6 n E)^{2}-12\left(2(n E)^{2}+\left(n-1+n b_{0}-a_{0}\right) \frac{n E^{2}}{c}\right.}}{6},
$$

Please note that if $n z^{*}<Z^{\#}$, the market experiences under-investment, which means that rational individual investors will invest less than the socially efficient level. This condition is fulfilled by the parameter specification in the proposed experiment (The detailed theoretical solution of Model 1 is provided in Supplementary Materials A).

\subsection{Model 2: An Open Innovation Investment with Uncertainty}

Investment is risky. Investors have to deal with the possibilities of an economic boom or a recession. In this setting, we assigned a $50 \%$ probability to both events. The expected rate of return is, therefore, the average level under both conditions:

$$
a_{0}=\frac{a_{0}^{-}+a_{0}^{+}}{2} ; b_{0}=\frac{b_{0}^{-}+b_{0}^{+}}{2},
$$

when the economic state is good, we observe $a_{0}=a_{0}^{+}$and $b_{0}=b_{0}^{+}$; the profit function reads:

$$
\mathrm{II}_{i}^{*+}=\left(1+a_{0}^{+}+a_{1}\right)+\left(z_{i}+z_{-i}\right)\left(1+b_{0}^{+}\right),
$$

when the economy is under recession or the economic state is bad, we observe $a_{0}=a_{0}^{-}$and $b_{0}=b_{0}^{-}$; the profit function reads:

$$
\mathrm{II}_{i}^{*-}=\left(1+a_{0}^{-}+a_{1}\right)+\left(z_{i}+z_{-i}\right)\left(1+b_{0}^{-}\right),
$$

where the optimal open innovation investment level determines the optimal profit level, which is the same as in Model 1 if we assume risk neutrality. The socially efficient solution is also the same as in Model 1.

\subsection{Parameters}

In the experiment, we set specific values for the parameters of interest. We assumed $\mathrm{a}_{0}=0.1, \mathrm{~b}_{0}=-0.4, \mathrm{a}_{0}^{+}=1.2, \mathrm{~b}_{0}^{+}=0.2, \mathrm{a}_{0}^{-}=-1, \mathrm{~b}_{0}^{-}=-1, \mathrm{c}=4, \mathrm{n}=4$, and $E=1000$. Then, we obtained the numerical solutions of the Nash equilibrium and the efficient outcomes for each model, as summarized in Table 1.

Table 1. Parameters of the models.

\begin{tabular}{ccc}
\hline & Model 1: No Uncertainty & Model 2: Uncertainty \\
\hline Endowment & 1000 & 1000 \\
\hline $\begin{array}{c}\text { Return Rate on Traditional } \\
\text { Innovation }\end{array}$ & $1.1+[0,4]$ & $\begin{array}{c}\text { Good State: } 2.2+[0,4] \\
\text { Bad State: } 0+[0,4]\end{array}$ \\
\hline Return Rate on Open Innovation & 0.6 & $\begin{array}{c}\text { Good State: } 1.2 \\
\text { Bad State: } 0\end{array}$ \\
\hline Symmetric Nash Equilibrium & 134 & 134 \\
\hline Efficient Solution & 530.15 & 530.15 \\
\hline
\end{tabular}

Source: Own table. Note: The Nash equilibrium and the efficient solution of Model 2 are the same as of Model 1, if risk neutrality of subjects is assumed.

\section{Experimental Design}

The proposed experiment aims at investigating the influence of different levels of social inducement on open innovation investment decisions under different levels of uncertainty. We frame the experiment 
as an individual's investment decision in the context of running a small company. This company, together with the other three companies, organizes an R\&D alliance. In line with the models described in Section 2, every subject decides how much of the given endowment (1000 experimental tokens) to allocate between traditional innovation and open innovation, which is beneficial to everybody in the alliance. The individual payoff consists of two payoff types. The first part of the payoff is derived from traditional investment and corresponds to the amount invested in traditional investment multiplied by the rate of return on traditional innovation. We assumed a spillover effect of open innovation on traditional innovation, which means that the rate of return of traditional innovation depends (positively) on the total level of open innovation within the R\&D alliance. The second part of the payoff is derived from open innovation investment and corresponds to the amount of open innovation investment in the whole group multiplied by the rate of return of the open innovation. Compared to Model 1, in Model 2, we allowed uncertainty, which makes the experiment more realistic and increases its external validity.

\subsection{Subject Pool and Recruitment Process}

We recruited students from the University of Nankai and Tianjin University in China, one student (assistant) from each university. With the help of the two assistants, we distributed flyers in canteens on the two campuses. Students could then register by email or telephone and provide their necessary demographic and educational information and their available time slots. Registered subjects were invited three or four days before a particular session via telephone calls or SMS, and they confirmed their availability. Those subjects received a reminder message in the evening before the experimental sessions.

We recruited 192 subjects from the University of Nankai and Tianjin University and divided them into 48 groups (i.e., four subjects per group). We conducted a computer-based experiment using Z-tree [64] in March and April 2015. All of the experimental sessions were conducted at the Smith Lab for Experimental Studies at the University of Nankai. Each subject only participated in one treatment session.

\subsection{Social Inducement}

The experiment is as follows. A video is used as a means of social inducement. The video is approximately six minutes long and conveys the following primary information (The original video is in Chinese. An English version video transcript is provided in Supplementary Materials B). It tells that traditional innovation with property rights protection is dominant and has been essential for achieving technological progress, but open innovation is an alternative and better business model for exploring innovation. To avoid that some experimental subjects are partially induced by the experimenters, the video reminds participants that free-riders may exist when one decides to contribute resources to open innovation. Since, in a real decision-making situation, people take much longer to understand open innovation.

The understanding and perception of open innovation may depend on the social inducement level available to the decision-makers. We aim to test whether watching a video about open innovation influences the level of investment in open innovation. For this purpose, we introduced three levels of social inducement to examine the potential differences:

1. The No-Video setting, in which subjects make investment decisions without any other information except standard instructions.

2. The Video settings, in which all the subjects watch the video before they turn to the game stage.

3. The Half-Video setting, in which only half the subjects in each group (i.e., two out of four) watch the video before the decision stage. This setting reflects the fact that social inducement in the real-world cannot reach everybody.

Combining two investment uncertainty levels and three different social inducement levels, we obtained a $2 \times 3$ design and a total of six treatments, as summarized in Table 2 . 
Table 2. Treatments.

\begin{tabular}{ccc}
\hline Treatment & Model & Social Instrument Level \\
\hline NoUn_NoV & Model 1: No Uncertainty & No-Video \\
NoUn_V & Model 1: No Uncertainty & Video \\
NoUn_HV & Model 1: No Uncertainty & Half-Video \\
\hline Un_NoV & Model 2: Uncertainty & No-Video \\
Un_V & Model 2: Uncertainty & Video \\
Un_HV & Model 2: Uncertainty & Half-Video \\
\hline
\end{tabular}

\subsection{Experimental Procedures}

All treatments include the same sequence of events, split into six subsequent steps, as shown in Figure 2 (The experimental instructions are provided in Supplementary Materials C). Participants first read the instructions and have the opportunity to pose clarifying questions (Step 1). To ensure that every subject understands the instructions and the general experimental process, participants were asked to answer four control questions (Step 2). Then, the subjects, including those in the Video setting and Half-Video setting, watched the video (Step 3). Please note that in the Half Video setting, subjects who watch the video were told in the introduction that only two subjects in the group of four will watch a video, while those who did not watch the video have no information about it. To prevent the non-watchers from occasionally seeing the video and being aware that some subjects are watching a video, curtains were pulled over each cabin during the whole experiment, and headsets were used for the video play. However, it is possible that some infer that other subjects receive extra information because they are requested to wait. Another point worth mentioning is that we only provided headsets to those cabins where the headsets were used for the video; hence, some may notice this difference among cabins and infer that they may be provided with different information. The decision stage is the core of the experiment (Step 4) and involves different treatment types, as summarized in Figure 2.

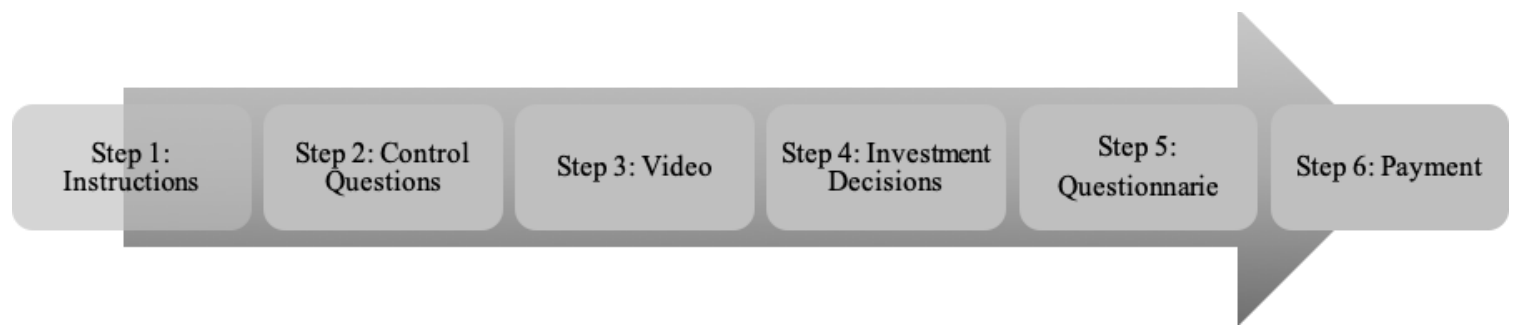

Figure 2. Sequence of Events.

Before making a real investment decision, the subject can use the payoff calculator on the left-hand side of the screen to simulate the investment outcomes for various investment environments (Supplementary Materials D shows a screenshot of the decision-making scenarios). He/she inputs the investment amount in open innovation projects and the estimated amount of the other three participants' total investment into open innovation projects and then clicks Calculate. The calculator shows the total investment sum in the group's open innovation project, the contributions a1 from the open innovation project to a traditional innovation project, the payoff that the subject receives from the open innovation project, the payoff that he/she obtains from the traditional innovation project, and his/her total payoff. The calculator is allowed to be used in each round. When the subject decides the amount of investment in the open innovation project, he/she inputs a number in the decision textbox on the right-hand side of the screen and then clicks OK. Subjects repeatedly make independent investment decisions in each round, for a total of ten rounds. After each round, all subjects are informed about the investment and payoffs of individuals and groups. 
The investment decision part is followed by a questionnaire comprising of socio-economic questions (Step 5), such as participants' gender, age, number of siblings, net monthly income, final school grade (National College Entrance Examination, NCEE; in Chinese pinyin, Gaokao), number of semesters attended, and field of studies. All subjects were also asked to report their risk attitude (0-10) and their ex-post attitude towards open innovation (0-10). We also asked them to indicate the primary criterion informing their investment decision, among a) payoff maximization, $b$ ) last round group average, $c$ ) random choice, and d) other. The total subject pool was summarized with respect to these variables in Table S1 and separately summarized with respect to different models in Table S2 (Model 1) and Table S3 (Model 2) in Supplementary Materials E.

At the end of the experimental session, subjects were privately paid (Step 6) with an exchange rate of 500 units of laboratory tokens to 1 RMB (approximately USD 0.161 , at that time). The final payoff consisted of the payoffs in all ten rounds. The experiment lasted approximately 60 minutes, and the average payoff was 53.6 RMB (approximately 8.6 USD), ranging between a minimum of 28.4 RMB and a maximum of $84.0 \mathrm{RMB}$. The expected payoffs were real average hourly wages that intended to reflect opportunity costs. To ensure a functioning incentive structure, we did not pay a lump-sum amount/show-up fee. Payoffs only depended on individual investment decisions, other group members' investment decisions, and the economic situation (economic boom or recession).

\section{Results and Discussion}

\subsection{Main Findings}

Figure 3 presents the summary results of the average contribution to open innovation investment at different levels of investment uncertainty across the three social inducement scenarios. At a general level, we observed a moderate contribution and end-round effects in both models, which is consistent with experiments based on a public good game $[65,66]$. Furthermore, the average contribution ranges between the Nash equilibrium (134) and the efficient investment level (530.15). This range fits the theoretical prediction. Figure $3 \mathrm{a}$ reports that, in the absence of uncertainty, subjects who are not induced contribute less than those in the inducement treatments. However, the average contribution in the Half-Video setting is substantially higher than that in the other two inducement levels in the presence of economic uncertainty, as shown in Figure 3b. This result seems to support the argument for promoting structural reforms under economic uncertainty (see, e.g., [67,68]).

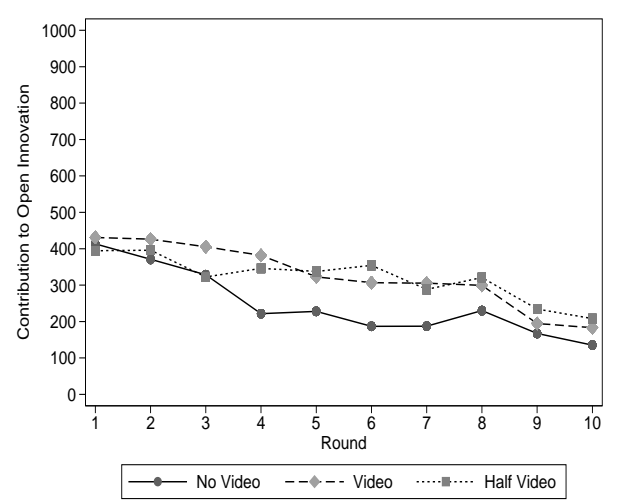

(a) Model 1: No Uncertainty

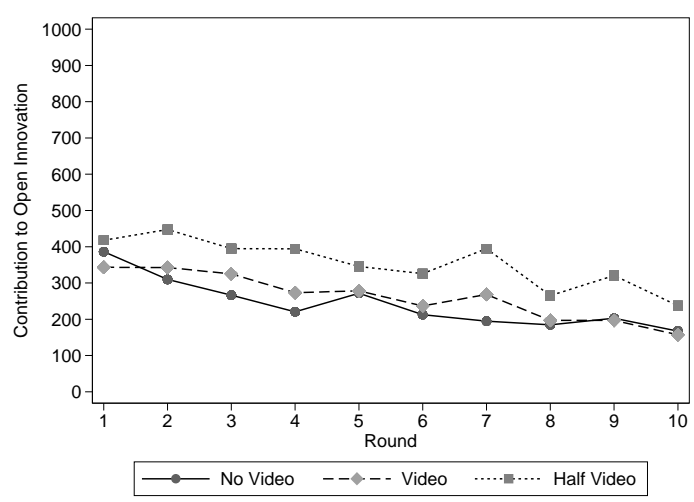

(b) Model 2: with Uncertainty

Figure 3. Overall average contributions in Model 1 and Model 2. Source: own calculation based on experimental data.

\subsection{Non-Parametric Tests and Regression Analysis}

To identify the impact of social inducement on open innovation contribution, we applied the two-sample Wilcoxon rank-sum test (z-statistic). First, we only looked at the first round. Since in 
the first round, other group members' decisions did not influence individual decisions, there were more independent observations, which ruled out the existence of learning effects in the experiments. We compared the No-Video setting with the Video and Half-Video settings, respectively, in both model scenarios, and we did not find a significant difference, which implies that, in the first round, social inducement had no significant influence on open innovation contribution in any level of inducement (Video or Half-Video) and model scenarios (certainty or uncertainty). We then extended the analysis to all ten rounds and found that social inducement only generated a statistically significant difference (112.6) between the No-Video and Half-Video treatments when economic uncertainty was present, and no significant difference was observed in other scenarios. Interestingly, there were also no significant differences between the complete four 'non-induced' and 'induced' subjects, that is, between treatments ' 1 ' and ' 2 ', in both models. The results are reported in Table 3.

Table 3. Non-parametric tests: main results.

\begin{tabular}{|c|c|c|c|c|c|c|}
\hline \multicolumn{7}{|c|}{ The First Round } \\
\hline & \multicolumn{3}{|c|}{ Model 1: No Uncertainty } & \multicolumn{3}{|c|}{ Model 2: Uncertainty } \\
\hline & No-Video & Video & Half-Video & No-Video & Video & Half-Video \\
\hline Mean Distribution & 413.5 & 431.1 & 394.5 & 386.3 & 343.4 & 417.8 \\
\hline$N$ (Group) & 8 & 8 & 8 & 8 & 8 & 8 \\
\hline $\begin{array}{c}\text { No-Video vs. } \\
\text { Video z-stat. ( } p \text {-value) }\end{array}$ & & $\begin{array}{c}-17.6 \\
-.36 \\
(0.723)\end{array}$ & & & $\begin{array}{c}42.8 \\
0.86(0.391)\end{array}$ & \\
\hline No-Video vs. Half & & 18.9 & & & -31.5 & \\
\hline Video & & -0.55 & & & -0.83 & \\
\hline z-stat. ( $p$-value) & & $(0.581)$ & & & $(0.408)$ & \\
\hline \multirow[t]{4}{*}{$N$ (Total) } & & 96 & & & 96 & \\
\hline & \multicolumn{6}{|c|}{ ALL ROUNDS } \\
\hline & \multicolumn{3}{|c|}{ Model 1: No Uncertainty } & \multicolumn{3}{|c|}{ Model 2: Uncertainty } \\
\hline & No-Video & Video & Half-Video & No-Video & Video & Half-Video \\
\hline \multirow{2}{*}{$\begin{array}{c}\text { Mean Distribution } \\
N \text { (Group) }\end{array}$} & 247.0 & 325.7 & 320.3 & 241.8 & 261.9 & 354.4 \\
\hline & 8 & 8 & 8 & 8 & 8 & 8 \\
\hline $\begin{array}{l}\text { No-Video vs. Video } \\
\text { z-stat. ( } p \text {-value) }\end{array}$ & \multicolumn{3}{|c|}{$\begin{array}{c}-78.7 \\
-1.58 \\
(0.115) \\
\end{array}$} & \multicolumn{3}{|c|}{$\begin{array}{c}-20.1 \\
-0.32 \\
(0.753)\end{array}$} \\
\hline $\begin{array}{l}\text { No-Video vs. Half } \\
\text { Video } \\
\text { z-stat. ( } p \text {-value) }\end{array}$ & \multicolumn{3}{|c|}{$\begin{array}{l}-73.3 \\
-1.16 \\
(0.248)\end{array}$} & \multicolumn{3}{|c|}{$\begin{array}{l}-112.6 \\
(0.005)\end{array}$} \\
\hline$N$ (Total) & \multicolumn{3}{|c|}{96} & \multicolumn{3}{|c|}{96} \\
\hline
\end{tabular}

The only significant difference that the Half-Video inducement created in Model 2 implies that social inducement worked better under economic uncertainty in the open innovation context, in line with the existing literature [69]. Moreover, the only significant difference in Model 2 was observed between the Half-Video and No-Video settings, not between the Video and No-Video settings, which raises the question of why asymmetric social inducement in the Half-Video setting generates better performance than full social inducement. However, based on the results reported in Table 3, we could not identify which factor, economic uncertainty or social inducement, leads the subjects to invest more in open innovation projects. If social inducement helps raise investment to open innovation, then, all induced subjects in both the Video and Half-Video settings should behave similarly. However, the results did not reveal such a similarity. Furthermore, why full social inducement does not generate a significant difference? We may suggest that homogenous information among group members reduced 
the contribution level, as other experiments also find that homogenous groups contribute less than heterogeneous groups [70]. Hence, we further investigated the role of economic uncertainty for the subjects in the Half-Video setting.

To control for additional influences, a regression analysis was conducted (Table 4) besides the standard non-parametric tests. The estimation results demonstrate that, in the presence of economic uncertainty, the Half-Video setting generates more open innovation than the No-Video setting, which is consistent with the non-parametric test results. In both models, risk preference is correlated with the contribution level, which is consistent with the literature [71]. Other factors, such as gender, age, the number of sisters and brothers, net monthly income, and education, including NCEE (Gaokao) grade and semesters attended, do not show any coherent and systematically significant effect.

Table 4. Regression analysis: main results.

\begin{tabular}{|c|c|c|c|}
\hline & \multicolumn{3}{|c|}{ Model 1: No Uncertainty } \\
\hline & $(1)$ & (2) & (3) \\
\hline \multicolumn{4}{|l|}{ Treatment Variable } \\
\hline Video & $78.7^{* *}$ & $74.5^{* *}$ & $70.7^{* *}$ \\
\hline Half-Video & 73.3 & 68.6 & 30.1 \\
\hline Stated Risk Performance (0-10) & & 16.6 & $21.9^{* *}$ \\
\hline Male & & & $-63.7^{* *}$ \\
\hline Age in Years & & & 3.8 \\
\hline N Siblings & & & 4.8 \\
\hline \multicolumn{4}{|l|}{ Net Monthly Income } \\
\hline 0-500 RMB & & & REF \\
\hline 501-1000 RMB & & & -10.0 \\
\hline 1001-2000 RMB & & & -42.2 \\
\hline 2001-3000 RMB & & & $-169.0^{*}$ \\
\hline More than $3000 \mathrm{RMB}$ & & & 170.2 \\
\hline Grade NEMT (Gaokao) & & & -0.2 \\
\hline$N$ Semester at University & & & -4.8 \\
\hline Constant & $247.0^{* * *}$ & $156.0^{* *}$ & 261.4 \\
\hline \multirow[t]{3}{*}{$N$} & 96 & 96 & 96 \\
\hline & \multicolumn{3}{|c|}{ Model 2: Uncertainty } \\
\hline & (1) & $(2)$ & (3) \\
\hline \multicolumn{4}{|l|}{ Treatment Variable } \\
\hline Video & 20.1 & 3.2 & 20.8 \\
\hline Half-Video & $112.6^{* * *}$ & $97.0^{* * *}$ & $104.7^{* *}$ \\
\hline Stated Risk Performance (0-10) & & $21.7^{* * *}$ & $22.7^{* * *}$ \\
\hline Male & & & -41.9 \\
\hline Age in Years & & & 9.9 \\
\hline N Siblings & & & 10.5 \\
\hline \multicolumn{4}{|l|}{ Net Monthly Income } \\
\hline 0-500 RMB & & & REF \\
\hline 501-1000 RMB & & & 44.0 \\
\hline 1001-2000 RMB & & & -5.0 \\
\hline 2001-3000 RMB & & & 2.4 \\
\hline More than $3000 \mathrm{RMB}$ & & & -1.7 \\
\hline Grade NEMT (Gaokao) & & & 0.3 \\
\hline$N$ Semester at University & & & 2.5 \\
\hline Constant & $241.8^{* * *}$ & $148.1^{* * *}$ & -261.9 \\
\hline$N$ & 96 & 96 & 96 \\
\hline
\end{tabular}

Source: own calculations based on experimental data. Note: reported values are coefficients from OLS regressions. ${ }^{*} p<0.10,{ }^{* *} p<0.05,{ }^{* * *} p<0.01$. Std. Err. adjusted for 24 clusters, each group of four subjects is one cluster. 


\subsection{The Impacts of the Half-Video Setting}

\subsubsection{The Behavior of the Watchers}

It has been shown that, on average, in the presence of economic uncertainty, the subjects in the Half-Video treatment invest more in open innovation than those in the No-Video treatment. However, this effect is not observed in the absence of uncertainty. We, therefore, concentrated on the significance of economic uncertainty for the decision-making of various subjects and identify what types of subjects contribute to this significantly high average.

To distinguish induced subjects in the Half-Video treatment, we termed the two subjects who watched the video as 'watchers' and the two who did not watch the video as 'non-watchers'. Moreover, we also addressed whether the watchers or the non-watchers were more influenced by social inducement and whether they invested more than the non-induced subjects in the No-Video treatment. Figure 4 shows the comparison of open innovation investment between non-induced subjects in the No-Video treatment and the watchers and the non-watchers in the Half-Video treatment. Both the watchers and the non-watchers contributed more to open innovation than the non-induced subjects did.

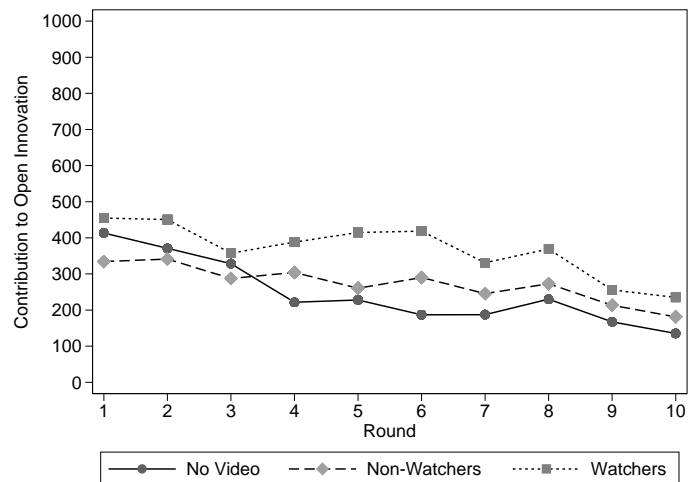

(a) Model 1: No Uncertainty

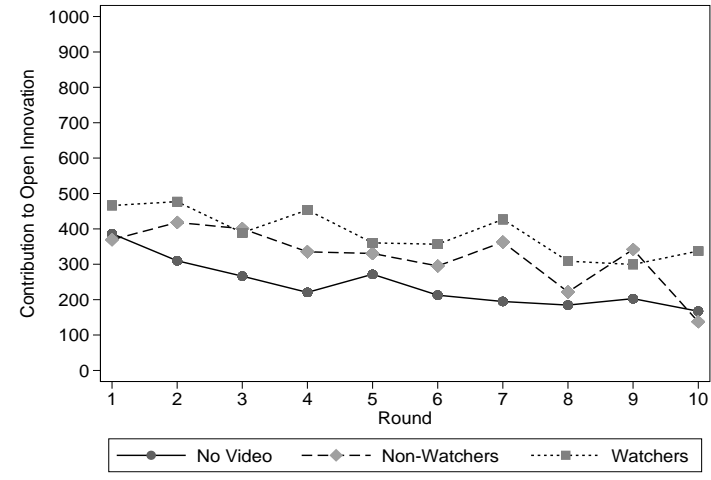

(b) Model 2: with Uncertainty

Figure 4. Model 1 and Model 2: No Video vs. Half Video (Watchers and non-Watchers). Source: own calculation based on experimental data.

The results reported in Table 5 show that the watchers invested more significantly in open innovation (120.5 and 145.8, respectively) compared with the non-induced subjects in the No-Video treatment, regardless of the economic certainty level. This result reflects the significant influence of social inducement on open innovation participation. 
Table 5. Non-parametric tests: watchers.

\begin{tabular}{|c|c|c|c|c|c|c|}
\hline & \multicolumn{3}{|c|}{ Model 1: No Uncertainty } & \multicolumn{3}{|c|}{ Model 2: Uncertainty } \\
\hline & No-Video & Video & $\begin{array}{c}\text { Half-Video } \\
\text { Watchers }\end{array}$ & No-Video & Video & $\begin{array}{c}\text { Half-Video } \\
\text { Watchers }\end{array}$ \\
\hline $\begin{array}{c}\text { Mean } \\
\text { Contribution }\end{array}$ & 247.0 & 325.7 & 367.5 & 241.8 & 261.9 & 387.5 \\
\hline$N$ (Group) & 8 & 8 & 8 & 8 & 8 & 8 \\
\hline $\begin{array}{l}\text { No Video vs. } \\
\text { Watchers }\end{array}$ & & -120.5 & & & -145.8 & \\
\hline z-stat. ( $p$-value) & & $\begin{array}{l}-1.89 \\
(0.059)\end{array}$ & & & $\begin{array}{l}-3.15 \\
(0.002)\end{array}$ & \\
\hline $\begin{array}{l}\text { Video vs. } \\
\text { Watchers }\end{array}$ & & -41.9 & & & -125.6 & \\
\hline z-stat. ( $p$-value) & & $\begin{array}{c}-0.21 \\
(0.834)\end{array}$ & & & $\begin{array}{l}-2.52 \\
(0.012)\end{array}$ & \\
\hline$N$ (Total) & & 80 & & & 80 & \\
\hline
\end{tabular}

Source: own calculations using experimental data. Note: tests are two-sample Wilcoxon rank-sum test (z-statistic). Watchers relate to subjects who saw the video in the Half Video setting.

Furthermore, by comparing the watchers in the Half-Video setting with the subjects in the Video setting, we found that in the model with uncertainty, the socially induced subjects (i.e., the watchers) who had non-induced group partners contributed significantly more (125.6) than the four watchers in the Video treatment, while this difference was equal to 41.9 but insignificant in the absence of economic uncertainty. This comparison shows that social inducement was more effective when non-induced partners were present in the group, which might explain why a significant treatment effect was observed in the Half-Video setting, in contrast with the Video setting, in the presence of uncertainty. This finding suggests that, given the existence of non-induced partners (non-watchers), economic uncertainty makes the socially induced subjects (watchers) more motivated to 'lead' and convey information to the non-induced subjects, and they committed to high-level open innovation as a signal. We confirmed the significance of asymmetric inducement within the group by comparing the non-induced subjects in different settings.

\subsubsection{The Behavior of The Non-Watchers}

We also investigated how the non-watchers behave in the Half-Video setting compared to the non-induced subjects in the No-Video setting. As Table 6 reveals, the non-watchers in the Half-Video treatment behaved similarly to the subjects in the No-video treatment in both models. The results from the last five rounds show that non-watchers contributed more than the subjects in the No-Video treatment when they face economic uncertainty (Such a difference is significant even in the last nine rounds. This difference is also significant in the regression analysis. See Table S4 in Supplementary Materials F). However, we did not observe this effect in the absence of uncertainty. This result supports our previous conclusions regarding the interactions between watchers and non-watchers when the economy is under uncertainty. 
Table 6. Non-parametric tests: non-watchers.

\begin{tabular}{|c|c|c|c|c|}
\hline \multicolumn{5}{|c|}{ ALL ROUNDS } \\
\hline & \multicolumn{2}{|c|}{ Model 1: No Uncertainty } & \multicolumn{2}{|c|}{ Model 2: Uncertainty } \\
\hline & No-Video & $\begin{array}{l}\text { Half-Video } \\
\text { Non-Watchers }\end{array}$ & No-Video & $\begin{array}{c}\text { Half-Video } \\
\text { Non-Watchers }\end{array}$ \\
\hline Mean Distribution & 247.0 & 273.1 & 241.8 & 321.3 \\
\hline$N($ Group $)$ & 8 & 8 & 8 & 8 \\
\hline No-Video vs. non-Watchers & \multirow{2}{*}{\multicolumn{2}{|c|}{$\begin{array}{c}-26.1 \\
0.11(0.916) \\
\end{array}$}} & \multirow{2}{*}{\multicolumn{2}{|c|}{$\begin{array}{c}-79.5 \\
-1.26(0.208) \\
\end{array}$}} \\
\hline z-stat. ( $p$-value) & & & & \\
\hline$N$ (Total) & \multicolumn{2}{|c|}{48} & \multicolumn{2}{|c|}{48} \\
\hline \multicolumn{5}{|c|}{ LAST FIVE ROUNDS } \\
\hline & \multicolumn{2}{|c|}{ Model 1: No Uncertainty } & \multicolumn{2}{|c|}{ Model 2: Uncertainty } \\
\hline & No-Video & $\begin{array}{c}\text { Half-Video } \\
\text { Non-Watchers }\end{array}$ & No-Video & $\begin{array}{c}\text { Half-Video } \\
\text { Non-Watchers }\end{array}$ \\
\hline Mean Distribution & 181.4 & 240.6 & 192.5 & 271.8 \\
\hline$N$ (Group) & 8 & 8 & 8 & 8 \\
\hline No-Video vs. non-Watchers & \multirow{2}{*}{\multicolumn{2}{|c|}{$\begin{array}{c}-59.2 \\
-0.74(0.462)\end{array}$}} & \multirow{2}{*}{\multicolumn{2}{|c|}{$\begin{array}{c}-79.2 \\
-1.68(0.092)\end{array}$}} \\
\hline z-stat. ( $p$-value) & & & & \\
\hline$N$ (Total) & \multicolumn{2}{|c|}{48} & \multicolumn{2}{|c|}{48} \\
\hline
\end{tabular}

Source: own calculations using experimental data. Note: tests are two-sample Wilcoxon rank-sum test (z-statistic). Non-Watchers relate to subjects who did not see the video in the Half Video setting.

\section{Conclusions}

We investigated the adoption of open innovation by addressing different investment uncertainty levels and spillover effects to conventional innovation and examined how social inducement impacts open innovation investment levels through laboratory experiments. The study's results revealed that the spillover effects represent a critical driving force for investors to share their ideas and resources; otherwise, contribution to open innovation would be risky due to the existence of free-riders. However, within a closed innovation context, a natural task for promoting the open innovation business paradigm should be spreading the perception, benefits, and risk of open innovation to the public and the business world. We proposed social inducement as a means to achieve this goal and examined the effectiveness of social inducement using an experimental approach, which contributed a unique external perspective to the open innovation literature, which usually focuses on the intrinsic economic motivations of individual people and business.

The experiment set three levels of social inducement under two different levels of investment uncertainty. We found that social inducement may be functional in leading subjects to invest more in open innovation projects, on average. The advantages of being open may not be a determining factor for businesses and individuals; however, open innovation can be a strategical approach to deal with economic uncertainty. Hence, the timing of social inducement is essential if inducement is applied.

Furthermore, the study's results demonstrated that two elements are crucial for establishing open innovation through social inducement. First, the existence of non-induced subjects made social inducement more effective. The asymmetric inducement setting induced agents to convey the value of open innovation to the non-induced ones. Hence, the media and public authorities should identify the critical group to promote the open innovation model. Compared with large-scale mass-oriented social inducements, targeting a particular group is not only cost-efficient but may also be more productive given the reaction of the non-targeted group. Second, economic uncertainty increased the effectiveness of social inducement. Hence, we suggest that in periods of high economic uncertainty, open innovation and related projects are easier to promote. Our findings may suggest practitioners and policymakers 
applying public channels to communicate open innovation concepts with the public, which in turn helps the adoption of open innovation.

This research suffered some limitations. We investigated the effects of social inducement on open innovation investment levels and confirmed its feasibility under certain conditions, but knew little about the causality. The findings and limitations open further research directions. We conclude the functionality and should identify the functioning mechanism of social inducement, and how the induced subject's perception of open innovation changes under social inducement. Besides, although we confirmed its function, formalizing social inducement in a business context is still a distant prospect.

Supplementary Materials: The following are available online at http://www.mdpi.com/2071-1050/12/5/2115/s1.

Author Contributions: Conceptualization and research design, S. D. and G.Y.; software, G.Y.; experiment and formal analysis, G.Y.; writing-original draft preparation, S.D. and G.Y.; writing-review and editing, S.D. All authors have read and agreed to the published version of the manuscript.

Funding: The German Federal Ministry of Education and Research (BMBF) funded this research. Moreover, we acknowledge support by the Open Access Publication Fund of the University of Duisburg-Essen.

Acknowledgments: We thank Jeannette Brosig-Koch, Timo Heinrich, Torsten Heinrich, and Lijia Tan for helpful comments. Furthermore, we thank Minqi Guan and Jiaxiu Zhang for their excellent research assistance.

Conflicts of Interest: The authors declare no conflict of interest.

\section{References}

1. Chesbrough, H.; Bogers, M. Explicating open innovation: Clarifying an emerging paradigm for understanding innovation. In New Frontiers in Open Innovation; Chesbrough, H., Vanhaverbeke, W., West, J., Eds.; Oxford University Press: Oxford, UK, 2014.

2. Cammarano, A.; Michelino, F.; Caputo, M. Open innovation practices for knowledge acquisition and their effects on innovation output. Technol. Anal. Strateg. Manag. 2019, 31, 1297-1313. [CrossRef]

3. Cammarano, A.; Michelino, F.; Lamberti, E.; Caputo, M. Accumulated stock of knowledge and current search practices: The impact on patent quality. Technol. Forecast. Soc. Chang. 2017, 120, 204-222. [CrossRef]

4. Enkel, E.; Gassmann, O.; Chesbrough, H. Open R\& D and open innovation: Exploring the phenomenon. $R D$ Manag. 2009, 39, 311-316.

5. Mahdad, M.; De Marco, C.E.; Piccaluga, A.; Di Minin, A. Harnessing adaptive capacity to close the pandora's box of open innovation. Ind. Innov. 2020, 27, 264-284. [CrossRef]

6. Ahn, J.M.; Minshall, T.; Mortara, L. Open innovation: A new classification and its impact on firm performance in innovative SMEs. J. Innov. Manag. 2015, 3, 33-54. [CrossRef]

7. Michelino, F.; Caputo, M.; Cammarano, A.; Lamberti, E. Inbound and Outbound Open Innovation: Organization and Performances. J. Technol. Manag. Innov. 2014, 9, 65-82. [CrossRef]

8. Liu, L. Sustainability: Living within one's own ecological means. Sustainability 2009, 1, 1412-1430. [CrossRef]

9. Scholz, R.W. Sustainable digital environments: What major challenges is humankind facing? Sustainability 2016, 8, 726. [CrossRef]

10. Curley, M.; Salmelin, B. Open Innovation 2.0: The New Mode of Digital Innovation for Prosperity and Sustainability; Springer: Cham, Switzerland, 2018.

11. Du, S.; Yalcinkaya, G.; Bstieler, L. Sustainability, social media driven open innovation, and new product development performance. J. Prod. Innov. Manag. 2016, 33, 55-71. [CrossRef]

12. Errichiello, L.; Micera, R. Leveraging Smart Open Innovation for Achieving Cultural Sustainability: Learning from a New City Museum Project. Sustainability 2018, 10, 1964. [CrossRef]

13. Yun, J.J.; Jeong, E.; Zhao, X.; Hahm, S.D.; Kim, K. Collective Intelligence: An Emerging World in Open Innovation. Sustainability 2019, 11, 4495. [CrossRef]

14. Arcese, G.; Flammini, S.; Lucchetti, M.C.; Martucci, O. Evidence and experience of open sustainability innovation practices in the food sector. Sustainability 2015, 7, 8067-8090. [CrossRef]

15. Benabou, R.; Tirole, J. Intrinsic and extrinsic motivation. Rev. Econ. Stud. 2003, 70, 489-520. [CrossRef]

16. Bogers, M.; Chesbrough, H.; Moedas, C. Open innovation: Research, practices, and policies. Calif. Manag. Rev. 2018, 60, 5-16. [CrossRef] 
17. Bogers, M.; Zobel, A.-K.; Afuah, A.; Almirall, E.; Brunswicker, S.; Dahlander, L.; Frederiksen, L.; Gawer, A.; Gruber, M.; Haefliger, S.; et al. The open innovation research landscape: Established perspectives and emerging themes across different levels of analysis. Ind. Innov. 2017, 24, 8-40. [CrossRef]

18. Chesbrough, H.W. Open Innovation: The New Imperative for Creating and Profiting from Technology; Harvard Business School Press: Boston, MA, USA, 2003.

19. Chesbrough, H.W. Open Business Models: How to Thrive in the New Innovation Landscape; Harvard Business School Press: Boston, MA, USA, 2006.

20. Chesbrough, H.W. Open Services Innovation: Rethinking your Business to Grow and Compete in a New Era; John Wiley \& Sons: San Francisco, CA, USA, 2010.

21. Chesbrough, H.W. The future of open innovation. Res. Technol. Manag. 2017, 60, 35-38. [CrossRef]

22. Chesbrough, H.W. Open Innovation Results: Going beyond the Hype E Getting down to Business; Oxford University Press: Oxford, UK, 2020.

23. Henkel, J.; Schöberl, S.; Alexy, O. The emergence of openness: How and why firms adopt selective revealing in open innovation. Res. Policy 2014, 43, 879-890. [CrossRef]

24. Quan, X.; Chesbrough, H.W. Hierarchical segmentation of R\&D process and intellectual property protection: Evidence from multinational R\&D laboratories in China. IEEE Trans. Eng. Manag. 2010, 57, 9-21.

25. von Hippel, E. Democratizing Innovation; MIT Press: Cambridge, MA, USA; London, UK, 2005.

26. West, J.; Bogers, M. Open innovation: Current status and research opportunities. Innov. Organ. Manag. 2017, 19, 43-50. [CrossRef]

27. West, J.; Salter, A.; Vanhaverbeke, W.; Chesbrough, H.W. Open innovation: the next decade. Res. Policy 2014, 43, 805-811. [CrossRef]

28. Laursen, K.; Salter, A.J. The paradox of openness: Appropriability, external search and collaboration. Res. Policy 2014, 43, 867-878. [CrossRef]

29. Afuah, A.; Tucci, C.L. Crowdsourcing as a solution to distant search. Acad. Manag. Rev. 2012, 3, 355-375. [CrossRef]

30. Cappa, F.; Oriani, R.; Pinelli, M.; De Massis, A. When does crowdsourcing benefit firm stock market performance. Res. Policy 2019, 48, 103825. [CrossRef]

31. Cappa, F.; Rosso, F.; Hayes, D. Monetary and Social Rewards for Crowdsourcing. Sustainability 2019, 11, 2834. [CrossRef]

32. de Araújo Burcharth, A.L.; Knudsen, M.P.; Søndergaard, H.A. Neither invented nor shared here: The impact and management of attitudes for the adoption of open innovation practices. Technovation 2014, 34, 149-161. [CrossRef]

33. Dolfsma, W.; van der Eijk, R. Behavioral foundations for open innovation: Knowledge gifts and social networks. Innov. Organ. Manag. 2017, 19, 287-306. [CrossRef]

34. Sørensen, F.; Mattsson, J.; Sundbo, J. Experimental methods in innovation research. Res. Policy 2010, 39, 313-322. [CrossRef]

35. Arundel, A.; Bloch, C.; Ferguson, B. Advancing innovation in the public sector: Aligning innovation measurement with policy goals. Res. Policy 2019, 48, 789-798. [CrossRef]

36. Clausen, T.H.; Demircioglu, M.A.; Alsos, G.A. Intensity of innovation in public sector organizations: The role of push and pull factors. Public Adm. 2019, 1-18. [CrossRef]

37. Popa, S.; Soto-Acosta, P.; Martinez-Conesa, I. Antecedents, moderators, and outcomes of innovation climate and open innovation: An empirical study in SMEs. Technol. Forecast. Soc. Chang. 2017, 118, 134-142. [CrossRef]

38. Sapprasert, K.; Clausen, T.H. Organizational innovation and its effects. Ind. Corp. Chang. 2012, 21, $1283-1305$. [CrossRef]

39. Urbano, D.; Turro, A.; Aparicio, S. Innovation through R\&D activities in the European context: Antecedents and consequences. J. Technol. Transf. 2019, 1-24. [CrossRef]

40. Rosenberg, N. The direction of technological change: Inducement mechanisms and focusing devices. Econ. Dev. Cult. Chang. 1969, 18, 1-24. [CrossRef]

41. Hirschman, A.O. The Strategy of Economic Development; Yale University Press: New Haven, CT, USA, 1958.

42. Veugelers, R. Which policy instruments to induce clean innovating? Res. Policy 2012, 41, 1770-1778. [CrossRef] 
43. Costantini, V.; Crespi, F. Public policies for a sustainable energy sector: Regulation, diversity and fostering of innovation. J. Evol. Econ. 2013, 23, 401-429. [CrossRef]

44. Ghisetti, C.; Marzucchi, A.; Montresor, S. The open eco-innovation mode. An empirical investigation of eleven European countries. Res. Policy 2015, 44, 1080-1093. [CrossRef]

45. Orihata, M.; Watanabe, C. The interaction between product concept and institutional inducement: A new driver of product innovation. Technovation 2000, 20, 11-23. [CrossRef]

46. Coffman, L.C.; Gotthard-Real, A. Moral Perceptions of Advised Actions. Manag. Sci. 2019, 65, $3904-3927$. [CrossRef]

47. Schram, A.; Charness, G. Inducing social norms in laboratory allocation choices. Manag. Sci. 2015, 61, 1531-1546. [CrossRef]

48. Simons, R.L. Inducement as an approach to exercising influence. Soc. Work 1985, 30, 56-62. [CrossRef]

49. DellaVigna, S.; Kaplan, E. The fox news effect: Media bias and voting. Q. J. Econ. 2007, 122, 187-1234. [CrossRef]

50. Yanagizawa-Drott, D. Propaganda and conflict: Evidence from the Rwandan genocide. Q. J. Econ. 2014, 129, 1947-1994. [CrossRef]

51. Kearney, M.S.; Levine, P.B. Media influences on social outcomes: The impact of mtv's 16 and pregnant on teen childbearing. Am. Econ. Rev. 2015, 105, 3597-3632. [CrossRef]

52. Bochet, O.; Page, T.; Putterman, L. Communication and punishment in voluntary contribution experiments. J. Econ. Behav. Organ. 2006, 60, 11-26. [CrossRef]

53. Brosig, J.; Weimann, J.; Ockenfels, A. The effect of communication media on cooperation. Ger. Econ. Rev. 2003, 4, 217-241. [CrossRef]

54. Dawes, R.M.; McTavish, J.; Shaklee, H. Behavior, communication, and assumptions about other people's behavior in a commons dilemma situation. J. Personal. Soc. Psychol. 1977, 35, 1-11. [CrossRef]

55. Isaac, R.M.; Walker, J.M. Communication and free-riding behavior: The voluntary contribution mechanism. Econ. Inq. 1988, 26, 585-608. [CrossRef]

56. Kessler, J.B. Announcements of support and public good provision. Am. Econ. Rev. 2017, 107, 3760-3787. [CrossRef]

57. Rivers, N.; Shenstone-Harris, S.; Young, N. Using nudges to reduce waste? The case of Toronto's plastic bag levy. J. Environ. Manag. 2017, 188, 153-162. [CrossRef]

58. Sunstein, C.R. Nudges, Agency, and Abstraction: A Reply to Critics. Rev. Philos. Psychol. 2015, 6, 511-529. [CrossRef]

59. Johnson, J.P. Open source software: Private provision of a public good. J. Econ. Manag. Strategy 2002, 11, 637-662. [CrossRef]

60. Lerner, J.; Tirole, J. Some simple economics of open source. J. Ind. Econ. 2002, 50, 197-234. [CrossRef]

61. West, J.; Gallagher, S. Challenges of open innovation: The paradox of firm investment in open-source software. R D Manag. 2006, 36, 319-331. [CrossRef]

62. Gould, D.M.; Gruben, W.C. The role of intellectual property rights in economic growth. J. Dev. Econ. 1996, 48, 323-350. [CrossRef]

63. Helpman, E. Innovation, imitation, and intellectual property rights. Econometrica 1993, 61, 1247-1280. [CrossRef]

64. Fischbacher, U. z-Tree: Zurich toolbox for ready-made economic experiments. Exp. Econ. 2007, 10, 171-178. [CrossRef]

65. Andreoni, J. Why free ride?: Strategies and learning in public goods experiments. J. Public Econ. 1988, 37, 291-304. [CrossRef]

66. Chaudhuri, A. Sustaining cooperation in laboratory public goods experiments: A selective survey of the literature. Exp. Econ. 2011, 14, 47-83. [CrossRef]

67. Bonfiglioli, A.; Gino, A.G. Economic Uncertainty and Structural Reforms; Economic Working Paper Series, No. 1494; Department of Economics and Business, Universitat Pompeu Fabra: Barcelona, Spain, 2018; Available online: https://econ-papers.upf.edu/papers/1494.pdf (accessed on 8 March 2020).

68. Fernandez, R.; Rodrik, D. Resistance to reform: Status quo bias in the presence of individual-specific uncertainty. Am. Econ. Rev. 1991, 81, 1146-1155.

69. Crutchfield, R.S. Conformity and character. Am. Psychol. 1955, 10, 191-198. [CrossRef] 
70. Burlando, M.; Guala, F. Heterogeneous agents in public goods experiments. Exp. Econ. 2005, 8, 35-54. [CrossRef]

71. Thaler, R.H.; Tversky, A.; Kahneman, D.; Schwartz, A. The effect of myopia and loss aversion on risk taking: An experimental test. Q. J. Econ. 1997, 112, 647-661. [CrossRef]

(C) 2020 by the authors. Licensee MDPI, Basel, Switzerland. This article is an open access article distributed under the terms and conditions of the Creative Commons Attribution (CC BY) license (http://creativecommons.org/licenses/by/4.0/). 